\title{
PENGARUH AKTIVITAS BELAJAR DAN KEMANDIRIAN BELAJAR TERHADAP HASIL BELAJAR MATEMATIKA SISWA SMP NEGERI 21 AMBON
}

\author{
Abdul Sofyan ${ }^{1}$, Tanwey Gerson Ratumanan ${ }^{2}$ \\ ${ }^{1,2}$ Program Studi Pendidikan Matematika Fakultas Keguruan dan Ilmu Pendidikan, Universitas Pattimura \\ Jalan Ir. M. Putuhena, Ambon, Indonesia \\ e-mail: ${ }^{1}$ abdulsofyan@gmail.com; ${ }^{2}$ gratumanan@yahoo.com
}

\begin{abstract}
Abstrak
Penelitian ini merupakan penelitian ex-post facto yang bersifat kausalitas dengan tujuan mengukur pengaruh langsung dan tidak langsung dari aktivias belajar dan kemandirian belajar terhadap hasil belajar. Penelitian dilakukan pada 151 siswa SMP Negeri 21 Ambon. Data dikumpulkan menggunakan metode observasi, angket, dan tes. Analisis data menggunakan statistik deskriptif dan Model Persamaan Struktural (SEM). Dari penelitian ini diperoleh hasil: (1) Terdapat pengaruh aktivitas belajar terhadap kemandirian belajar siswa secara langsung sebesar 19,6\%, termasuk kategori sedang; (2) Terdapat pengaruh aktivitas belajar terhadap hasil belajar matematika siswa secara langsung sebesar 18,66\%, termasuk kategori sedang; (3) Terdapat pengaruh kemandirian belajar terhadap hasil belajar matematika siswa secara langsung sebesar 11,9\%, termasuk kategori rendah; (4) Terdapat pengaruh aktivitas belajar terhadap hasil belajar matematika siswa secara tidak langsung melalui kemandirian belajar sebesar 2,34 \%, termasuk kategori rendah; (5) Total pengaruh aktivitas belajar terhadap hasil belajar matematika siswa baik secara langsung maupun tidak langsung melalui kemandirian belajar sebesar 34,1\% termasuk kategori besar
\end{abstract}

Kata Kunci: aktivitas belajar, kemandirian belajar, pengaruh langsung, pengaruh tidak langsung, model persamaan struktural

\section{THE EFFECT OF LEARNING AND INDEPENDENCE ACTIVITIESON STUDENTD MATHEMATICAL LEARNING OUTCOMES OF SMA NEGERI 21 AMBON}

\begin{abstract}
This study is ex-post facto studythat is causal in nature in order to measure the direct and indirect effects of learning and independence of learning activities on learning outcomes. The study was conducted on 151 students of SMP Negeri 21 Ambon. Data was collected using observation, questionnaires, and tests. Data analysis used descriptive statistics and Structural Equation Model (SEM). From this study the results were obtained: (1) There was an effect of learning activities on student self-learning directly by $19.6 \%$, including the medium category; (2) There is an influence of learning activities on students' mathematics learning outcomes directly by $18.66 \%$, including the medium category; (3) There is an effect of learning independence on students' mathematics learning outcomes directly by $11.9 \%$, including the low category; (4) There is an influence of learning activities on student mathematics learning outcomes indirectly through learning independence by $2.34 \%$, including low categories; (5) Total effect of learning activities to students' mathematics learning outcomes either directly or indirectly through independent learning $34.1 \%$ including the big categories

Keywords: learning activity, independent learning, direct effect, indirect effect, a structural equation model
\end{abstract}




\section{Pendahuluan}

Matematika merupakan mata pelajaran yang dianggap penting dipelajari dan dikuasai oleh peserta didik. Terdapat banyak manfaat mempelajari matematika, di antaranya (1) membantu memecahkan masalah baik dalam kehidupan, (2) mengembangkan kemampuan berpikir logis, (3) mengembangkan kemampuan visualisasi dan abstraksi, dan (4) memberikan dasar bagi pengembangan berbagai bidang ilmu. Karena manfaatnya yang besar tersebut, matematika diajarkan mulai dari sekolah dasar sampai dengan perguruan tinggi.

Sayangnya, fakta menunjukkan bahwa banyak siswa kurang tertarik mempelajari matematika. Selain itu banyak hasil penelitian juga menunjukkan bahwa hasil belajar matematika siswa relatif rendah (Ratumanan, 2015). Banyak factor yang mempengaruhi hasil belajar matematika siswa, anara lain aktivitas belajar dan kemandirian belajar. Ernawati (2013: 41) mengemukakan bahwa faktor aktivitas belajar sangat penting peranannya dalam mencapai hasil belajar karena terkait dengan kegiatan yang menjadi program-program sekolah. Proses belajar merupakan suatu hal yang kompleks dan siswalah yang menentukan terjadi dan tidaknya belajar, sehingga siswa dituntut aktif dan mandiri dalam belajarnya. Perwujudan pembelajaran yang baik dapat dilihat dari aktivitas belajar dalam mengikuti pelajaran. Dapat disimpulkan semakin tinggi aktivitas belajar semakin tinggi pula hasil belajar. Dierich (Yamin, 2013: 84) membagi aktivitas belajar dalam delapan aspek, yaitu: a) Kegiatan visual; b) Kegiatan lisan (oral); c) Kegiatan mendengarkan; d) Kegiatan menulis; e) Kegiatan menggambar; f) Kegiatan metrik; g) Kegiatan mental; h) Kegiatan emosional.

Di samping aktivitas belajar, hasil belajar juga dipengaruhi oleh kemandirian belajar. Kemandirian menekankan pada aktivitas siswa dalam belajar yang penuh tanggung jawab atas keberhasilan dalam belajar. Ernawati (2013: 3) mengemukakan bahwa kemandirian siswa dalam belajar merupakan salah satu faktor penting yang harus diperhatikan untuk mencapai hasil belajar yang baik. Berkaitan dengan proses pembelajaran di sekolah, siswa dikatakan telah belajar secara mandiri apabila telah mampu melakukan tugas belajar tanpa ketergantungan dengan orang lain. Kemandirian dalam belajar dapat diartikan sebagai aktivitas belajar dan berlangsungnya lebih didorong oleh kemauan sendiri, pilihan sendiri dan tanggung jawab sendiri dari siswa. Steinberg (Nurhayati, 2011: 133), mengemukakan bahwa kemandirian belajar secara psikososial tersusun dari tiga aspek pokok yaitu: 1) Mandiri emosi; 2) Mandiri perilaku; dan 3) Mandiri nilai.

Berdasarkan hasil observasi peneliti di SMP Negeri 21 Ambon pada tanggal 21 September 2014, kenyataan menunjukkan bahwa sebagian besar siswa dalam mengerjakan tugas-tugas yang diberikan oleh guru banyak siswa yang mengambil cara cepat dengan hanya menyalin jawaban dari teman tanpa memahami jawaban tersebut. Bagi mereka yang penting mengerjakan dan dapat mempertanggungjawabkan dihadapan guru dengan menunjukkan pekerjaannya. Kemudian jika guru menanyakan kepada siswa apa yang tidak siswa pahami, para siswa hanya diam dan tidak merespon pertanyaan guru. Begitupun ketika diskusi hanya sebagian kecil siswa yang terlihat aktif dalam diskusi. Hal-hal tersebut menunjukkan bahwa aktivitas belajar dan kemandirian belajar siswa kurang.

Bertolak dari uraian di atas, pembelajaran perlu dikembangkan untuk memacu aktivitas dan kemandirian siswa dalam belajar. Siswa yang kemandirian tinggi mampu belajar tanpa bantuan orang lain. Sedangkan siswa yang mempunyai kemandirian belajar rendah sangat memerlukan orang lain dalam belajarnya. Hal ini sangat berpengaruh terhadap hasil belajar.

Berdasarkan latar belakang yang telah dikemukakan di atas, maka rumusan masalah dalam penelitian ini yaitu: (1) Seberapa besar pengaruh langsung aktivitas belajar terhadap kemandirian belajar matematika siswa SMP Negeri 21 Ambon? (2) Seberapa besar pengaruh langsung aktivitas belajar terhadap hasil belajar matematika siswa SMP Negeri 21 Ambon? (3) Seberapa besar pengaruh langsung kemandirian belajar terhadap hasil belajar matematika siswa SMP Negeri 21 Ambon? (4) Seberapa besar pengaruh tidak langsung aktivitas belajar terhadap hasil belajar matematika siswa SMP Negeri 21 Ambon melalui kemandirian belajar? (5) Seberapa besar total pengaruh aktivitas belajar terhadap hasil belajar matematika siswa SMP Negeri 21 Ambon baik secara langsung maupun tidak langsung melalui kemandirian belajar?

Adapun tujuan penelitian ini adalah untuk mengetahui beberapa hal sebagai berikut: (1) Besar pengaruh langsung aktivitas belajar terhadap kemandirian belajar matematika siswa SMP Negeri 21 Ambon; (2) Besar pengaruh langsung aktivitas belajar terhadap hasil belajar matematika siswa SMP Negeri 21 Ambon; (3) Besar pengaruh langsung kemandirian belajar terhadap hasil belajar matematika siswa SMP Negeri 21 Ambon; (4) Besar pengaruh tidak langsung aktivitas belajar terhadap hasil belajar matematika siswa SMP Negeri 21 Ambon melalui 
kemandirian belajar; (5) Besar total pengaruh aktivitas belajar terhadap hasil belajar matematika siswa SMP Negeri 21 Ambon baik secara langsung maupun tidak langsung melalui kemandirian belajar

\section{Metode Penelitian}

Penelitian ini adalah penelitian ex-post facto yang bersifat kausalitas. Peneliti dalam hal ini akan menelusuri hubungan sebab akibat (kausal) dan menguji hipotesis yang telah dirumuskan sebelumnya antara: aktivitas belajar dan kemandirian belajar terhadap hasil belajar matematika. Populasi dalam penelitian ini adalah seluruh siswa SMP Negeri 21 Ambon tahun ajaran 2015/2016. Teknik penentuan sampel dilakukan melalui dua tahap. Pada pemilihan tahap pertama, karena sampel yang diambil heterogen, yaitu terbagi dalam tiga tingkatan kelas maka pengambilan sampel dalam penelitian ini menggunakan teknik Proportionate Stratified Random Sampling. Pada tahap kedua menentukan kelas yang akan dijadikan sampel penelitian secara acak (random) yang mewakili kelas VII, kelas VIII dan kelas IX.

Instrumen penelitian berupa, a) angket aktivitas belajar dan kemandirian belajar yang dibagikan kepada siswa; b) dokumentasi hasil belajar yang diperoleh dari hasil tes tengah semester genap yang sudah dilakukan guru mata pelajaran matematika sebelumnya. Data yang telah diperoleh selanjutnya dianalisis dengan menggunakan teknik analisis statistik deskriptif dan statistik inferensial. Untuk keperluan pengujian hipotesis digunakan Metode Structural Equation Modelling (SEM). Dalam teknik analisis SEM ini menggunakan paket program SPSS versi 20 dan AMOS (Analysis of Moment Structure) versi 20

\section{Hasil dan Pembahasan}

\subsection{Uji Asumsi}

Terdapat tiga asumsi yang harus dipenuhi dalam uji Structural Equation Modelling (SEM), yakni (1) kecukupan informasi (overidentified), (2) normalitas, dan (3) tidak terdapat data outlier. Pertama, untuk mengidentifikasi model apakah layak dianalisis lebih lanjut dapat diketahui dengan konsep derajat kebebasan (degree of freedom). Dari output AMOS bagian notes for model diperoleh $\mathrm{df}=42>0$, yang berarti bahwa cukup informasi (overidentified) atau layak dianalisis lebih lanjut. Kedua, Asumsi normalitas data diuji dengan melihat nilai skewness dan kurtosis dari data yang diperoleh.

Apabila nilai C.R pada skewness atau kurtosis berada pada rentang antara $\pm 2,58$, maka data masih dapat dinyatakan berdistribusi normal. Hasil pengujian normalitas data memperlihatkan bahwa tidak ada satupun nilai C.R kurtosis secara univariate dan multivariate data aktivitas belajar dan kemandirian belajar yang berada di luar rentang nilai $\pm 2,58$, maka disimpulkan data berdistribusi normal. Ketiga, Outliers adalah observasi yang muncul dengan nilai-nilai ekstrim karena kombinasi karakteristik unik yang dimilikinya yang terlihat sangat jauh berbeda dari observasi-observasi.

\subsection{Analisis Structural Equation Modelling (SEM)}

Berdasarkan Model Tahap Akhir, hasil analisis yang diperoleh, disajikan pada Gambar 1.

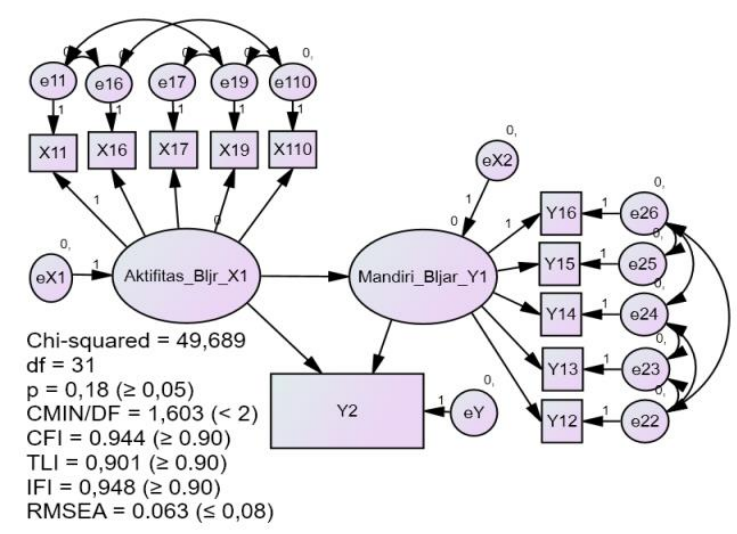

Gambar 1. Model Faktor-Faktor dari Hasil Belajar Siswa Tahap Akhir

Gambar 1. menghasilkan indeks overall fit untuk model tahap akhir adalah nilai $p=0,18>$ $0,05, \mathrm{CMIN} / \mathrm{DF}=1,603<2, \mathrm{CFI}=0,944$, RMSEA $=0,063<0,080$, TLI $=0,901$ dan IFI $=$ 0,948 serta probabilitas untuk chi-squared untuk model tahap akhir lebih kecil daripada model tahap awal sehingga telah menunjukkan acceptable fit. Jadi, telah memenuhi minimal 3 indeks untuk dapat dijadikan patokan kecocokan model. Dengan demikian model ini dapat diterima untuk analisis lebih lanjut.

Tabel 1. Regression Weights

\begin{tabular}{|c|c|c|c|c|c|}
\hline Hubungan antar Variabel & Estimate & S.E. & C.R. & $\mathrm{P}$ & Label \\
\hline $\begin{array}{lll}\text { Kemandirian } & <--- & \text { Aktivitas } \\
\text { Belaiar (Y1) } & & \text { Belajar (X) }\end{array}$ & 0,462 & 0,175 & 2,639 & 0,008 & par_8 \\
\hline
\end{tabular}




\begin{tabular}{llllllll}
\hline $\begin{array}{l}\text { Hasil Belajar } \\
\text { (Y2) }\end{array}$ & $<---$ & $\begin{array}{l}\text { Aktivitas } \\
\text { Belajar (X) }\end{array}$ & 10,727 & 3,403 & 3,153 & 0,002 & par_10 \\
\hline $\begin{array}{l}\text { Hasil Belajar } \\
\text { (Y2) }\end{array}$ & $<---$ & $\begin{array}{l}\text { Kemandirian } \\
\text { Belajar (Y1) }\end{array}$ & 8,198 & 2,600 & 3,153 & 0,002 & par_11 \\
\hline
\end{tabular}

Persamaan struktural yang sesuai dengan Model Tahap Akhir dan korelasi multipel kuadratnya sebagaimana dalam Tabel 3.1 di atas adalah sebagai berikut:

$$
\begin{array}{ll}
\hat{Y}_{1}=0,462 \hat{X}+0,11, R_{y 1}^{2}=19,6 \% & (1) \\
\hat{Y}_{2}=10,727 \hat{X}+8,198 \hat{Y}_{1}+43,47, & R_{Y 2}^{2}=43,7 \%
\end{array}
$$

Dengan $\hat{X}$ adalah aktivitas belajar dan $\hat{Y}_{1}$ dan $\hat{Y}_{2}$ berturut-turut adalah kemandirian belajar dan hasil belajar matematika.

Tabel 2. Standardized Regression Weight

\begin{tabular}{llll}
\hline \multicolumn{2}{l}{ Koefisien Regresi Terstandarisasi } & Estimate \\
\hline $\begin{array}{l}\text { Kemandirian } \\
\text { Belajar (Y1) }\end{array}$ & $<---$ & Aktivitas & 0,443 \\
& & Belajar (X) & \\
\hline $\begin{array}{l}\text { Hasil Belajar } \\
\text { (Y2) }\end{array}$ & $<---$ & $\begin{array}{l}\text { Aktivitas } \\
\text { Belajar (X) }\end{array}$ & 0,432 \\
\hline $\begin{array}{l}\text { Hasil Belajar } \\
\text { (Y2) }\end{array}$ & $<---$ & $\begin{array}{l}\text { Kemandirian } \\
\text { Bemaj (Y1) }\end{array}$ & 0,345 \\
\hline
\end{tabular}

Berdasarkan hasil analisis data, maka hasilhasil pengujian hipotesis penelitian yang dinyatakan dalam hipotesis statistik, sebagai berikut:

\subsubsection{Uji hipotesis penelitian menyangkut prediksi langsung}

Berdasarkan hasil pengolahan data pada Tabel 3.1 dan Tabel 3.2 untuk model tahap akhir yang diperoleh, maka pengujian hipotesis penelitian prediksi langsung dikemukakan sebagai berikut:

a. Uji hipotesis pertama

Hipotesis statistik pertama yang akan diuji adalah

$\mathrm{H}_{0}: \hat{\gamma}_{11}=0$ melawan $\mathrm{H}_{1}: \hat{\gamma}_{11}>0$

dimana $\mathrm{H}_{1}$ menyatakan bahwa aktivitas belajar (X) berpengaruh positif terhadap kemandirian belajar matematika $\left(\mathrm{Y}_{1}\right)$ siswa SMP Negeri 21 Ambon. Sebagaimana ditunjukkan dalam Tabel 3.2, diperoleh bobot koefisien regresi terstandarisasi aktivitas belajar terhadap kemandirian belajar matematika $\left(\hat{\gamma}_{11}\right)$ sebesar 0,443 atau $R^{2}=$ $(0,443)^{2}=19,6 \%$ dengan nilai $\mathrm{p}=0,008<$ 0,05 . Ini berarti bahwa $\mathrm{H}_{0}$ ditolak pada taraf signifikansi 0,05 . Jadi, ada pengaruh positif dan signifikan aktivitas belajar (X) terhadap kemandirian belajar matematika $\left(\mathrm{Y}_{1}\right)$ pada taraf signifikansi 0,05 .
Effect size untuk hipotesis pertama diperoleh:

$f^{2}=\frac{R^{2}}{1-R^{2}}=\frac{0,196}{1-0,196}=\frac{0,196}{0,804}=0,244$ (sedang)

Berdasarkan perhitungan effect size dapat disimpulkan bahwa aktivitas belajar mempunyai kekuatan pengaruh yang sedang dalam mempengaruhi kemandirian belajar

b. Uji hipotesis kedua

Hipotesis statistik kedua yang akan diuji adalah

$\mathrm{H}_{0}: \hat{\gamma}_{21}=0$ melawan $\mathrm{H}_{1}: \hat{\gamma}_{21}>0$

dimana $\mathrm{H}_{1}$ menyatakan bahwa aktivitas belajar $(\mathrm{X})$ berpengaruh positif terhadap hasil belajar matematika $\left(\mathrm{Y}_{2}\right)$ siswa SMP Negeri 21 Ambon. Sebagaimana ditunjukkan dalam Tabel 3.2, diperoleh bobot koefisien regresi terstandarisasi aktivitas belajar terhadap hasil belajar matematika $\left(\hat{\gamma}_{21}\right)$ sebesar 0,432 atau $R^{2}=(0,432)^{2}=18,66 \%$ dengan nilai $\mathrm{p}=$ $0,002<0,05$. Ini berarti bahwa $\mathrm{H}_{0}$ ditolak pada taraf signifikansi 0,05. Jadi, ada pengaruh positif dan signifikan aktivitas belajar (X) terhadap hasil belajar matematika $\left(\mathrm{Y}_{2}\right)$ pada taraf signifikansi 0,05 .

Effect size untuk hipotesis kedua diperoleh:

$f^{2}=\frac{R^{2}}{1-R^{2}}=\frac{0,1866}{1-0,1866}=\frac{0,1866}{0,8134}=0,229$ (sedang)

Berdasarkan perhitungan effect size dapat disimpulkan bahwa aktivitas belajar mempunyai kekuatan pengaruh yang sedang dalam mempengaruhi hasil belajar.

c. Uji hipotesis ketiga

Hipotesis statistik ketiga yang akan diuji adalah

$\mathrm{H}_{0}: \hat{\beta}_{21}=0$ melawan $\mathrm{H}_{1}: \hat{\beta}_{21}>0$

dimana $\mathrm{H}_{1}$ menyatakan bahwa

kemandirian belajar $\left(\mathrm{Y}_{1}\right)$ berpengaruh positif terhadap hasil belajar matematika $\left(\mathrm{Y}_{2}\right)$ siswa SMP Negeri 21 Ambon. Sebagaimana ditunjukkan dalam Tabel 3.2., diperoleh bobot koefisien regresi terstandarisasi kemandirian belajar terhadap hasil belajar matematika ( $\left.\hat{\beta}_{21}\right)$ sebesar 0,345 atau $R^{2}=$ $(0,345)^{2}=11,9 \%$ dengan nilai $\mathrm{p}=0,002<$ 0,05 . Ini berarti bahwa $\mathrm{H}_{0}$ ditolak pada taraf signifikansi 0,05 . Jadi, ada pengaruh positif dan signifikan kemandirian belajar $\left(\mathrm{Y}_{1}\right)$ terhadap hasil belajar matematika $\left(\mathrm{Y}_{2}\right)$. 
Effect size untuk hipotesis kedua diperoleh:

$f^{2}=\frac{R^{2}}{1-R^{2}}=\frac{0,119}{1-0,119}=\frac{0,119}{0,881}=0,135 \quad($ kecil $)$

Berdasarkan perhitungan effect size dapat disimpulkan bahwa kemandirian belajar mempunyai kekuatan pengaruh yang kecil dalam mempengaruhi hasil belajar.

\subsubsection{Uji hipotesis penelitian menyangkut prediksi tidak langsung (mediator)}

Tabel 3. Pengaruh Tidak Langsung Antar Variabel

\begin{tabular}{|c|c|c|}
\hline & $\begin{array}{l}\text { Aktivitas } \\
\text { Belajar (X) }\end{array}$ & $\begin{array}{l}\text { Kemandirian } \\
\text { belajar (Y1) }\end{array}$ \\
\hline \multicolumn{3}{|c|}{ Indirect Effect-Estimates } \\
\hline $\begin{array}{l}\text { Kemandirian Belajar } \\
\text { (Y1) }\end{array}$ & - & - \\
\hline Hasil Belajar (Y2) & 3,788 & - \\
\hline \multicolumn{3}{|c|}{ Standardized Indirect Effects } \\
\hline & $\begin{array}{l}\text { Aktivitas } \\
\text { Belajar (X) }\end{array}$ & $\begin{array}{l}\text { Kemandirian } \\
\text { belajar (Y1) }\end{array}$ \\
\hline $\begin{array}{l}\text { Kemandirian Belajar } \\
\text { (Y1) }\end{array}$ & - & - \\
\hline Hasil Belajar (Y2) & 0,153 & - \\
\hline
\end{tabular}

Uji hipotesis keempat

Hipotesis statistik keempat yang akan diuji adalah

$$
\mathrm{H}_{0}: \hat{\beta}_{21} \hat{\gamma}_{11}=0 \text { melawan } \mathrm{H}_{1}: \hat{\beta}_{21} \hat{\gamma}_{11}>0
$$

dimana $\mathrm{H}_{1}$ menyatakan bahwa aktivitas belajar (X) memiliki pengaruh tidak langsung yang positif terhadap hasil belajar $\left(\mathrm{Y}_{2}\right)$ melalui kemandirian belajar $\left(\mathrm{Y}_{1}\right)$ siswa SMP Negeri 21 Ambon. Sebagaimana ditunjukkan dalam Tabel 3.3, diperoleh bobot koefisien regresi standardized indirect effects aktivitas belajar terhadap hasil belajar matematika melalui kemandirian belajar matematika $\left(\hat{\beta}_{21} \hat{\gamma}_{11}\right)$ sebesar 0,153 atau $R^{2}=(0,153)^{2}=2,34 \%$ dengan nilai $\mathrm{p}$ $=0,043<0,05$ (Lampiran 12). Ini berarti bahwa $\mathrm{H}_{0}$ ditolak pada taraf signifikansi 0,05 . Jadi, ada pengaruh positif dan signifikan aktivitas belajar (X) terhadap hasil belajar matematika $\left(\mathrm{Y}_{2}\right)$ melalui kemandirian belajar matematika $\left(\mathrm{Y}_{1}\right)$ pada taraf signifikansi 0,05.

Effect size untuk hipotesis kedua diperoleh:

$$
f^{2}=\frac{R^{2}}{1-R^{2}}=\frac{0,0234}{1-0,0234}=\frac{0,0234}{0,9766}=0,024 \text { (kecil) }
$$

Berdasarkan perhitungan effect size dapat disimpulkan bahwa aktivitas belajar mempunyai kekuatan pengaruh yang kecil dalam mempengaruhi hasil belajar matematika melalui kemandirian belajar matematika.

\subsubsection{Uji hipotesis penelitian menyangkut total pengaruh (langsung dan tidak langsung) \\ Uji hipotesis kelima \\ Hipotesis statistik kelima yang akan diuji} adalah

$\mathrm{H}_{0}: \hat{\gamma}_{21}+\hat{\beta}_{21} \hat{\gamma}_{11}=0$ melawan $\mathrm{H}_{1}: \hat{\gamma}_{21}+\hat{\beta}_{21} \hat{\gamma}_{11}>0$ dimana $\mathrm{H}_{1}$ menyatakan bahwa total pengaruh aktivitas belajar (X) terhadap hasil belajar matematika $\left(\mathrm{Y}_{2}\right)$ siswa SMP Negeri 21 Ambon baik secara langsung maupun tidak langsung melalui kemandirian belajar $\left(\mathrm{Y}_{1}\right)$ adalah positif. Sebagaimana ditunjukkan dalam Tabel 3.4, diperoleh bobot koefisien regresi standardized total effects aktivitas belajar terhadap hasil belajar matematika $\hat{\gamma}_{21}+\hat{\beta}_{21} \hat{\gamma}_{11}$ sebesar 0,584 atau $R^{2}=$ $(0,584)^{2}=34,1 \%$ dengan nilai $\mathrm{p}=0,001<0,05$. Ini berarti bahwa $\mathrm{H}_{0}$ ditolak pada taraf signifikansi 0,05. Jadi, total pengaruh aktivitas belajar $(\mathrm{X})$ terhadap hasil belajar matematika $\left(\mathrm{Y}_{2}\right)$ baik secara langsung maupun tidak langsung melalui kemandirian belajar $\left(\mathrm{Y}_{1}\right)$ adalah positif dan signifikan pada taraf signifikansi 0,05.

Effect size untuk hipotesis kedua diperoleh:

$$
f^{2}=\frac{R^{2}}{1-R^{2}}=\frac{0,341}{1-0,341}=\frac{0,341}{0,659}=0,517 \text { (besar) }
$$

Berdasarkan perhitungan effect size dapat disimpulkan bahwa total pengaruh aktivitas belajar terhadap hasil belajar matematika baik secara langsung maupun tidak langsung melalui kemandirian belajar mempunyai kekuatan

\begin{tabular}{|c|c|c|}
\hline & $\begin{array}{l}\text { Aktivitas Belajar } \\
(\mathrm{X})\end{array}$ & $\begin{array}{l}\text { Kemandirian } \\
\text { Belajar (Y1) }\end{array}$ \\
\hline \multicolumn{3}{|c|}{ Total Effect-Estimates } \\
\hline (Y1) & 0,462 & - \\
\hline$(\mathrm{Y} 2)$ & 14,515 & 8,198 \\
\hline \multicolumn{3}{|c|}{ Standardized Total Effects } \\
\hline (Y1) & 0,443 & - \\
\hline$(\mathrm{Y} 2)$ & 0,584 & 0,345 \\
\hline \multicolumn{3}{|c|}{ Total Effect-Significance (nilai-p) } \\
\hline (Y1) & 0,008 & - \\
\hline (Y2) & 0,001 & 0,002 \\
\hline
\end{tabular}
pengaruh yang besar.

Tabel 4 Pengaruh Total Antar Variabel

Berdasarkan hasil verifikasi model dan hasil-hasil pengujian hipotesis sebagaimana telah dikemukakan di atas, berikut dikemukakan pembahasan terhadap hasil yang diperoleh.

Persamaan regresi dan korelasi multipel kuadrat (4.1) menunjukkan bahwa sekitar 19,6\% variabel kemandirian belajar matematika siswa dapat dijelaskan oleh aktivitas belajar dalam belajar matematika. Sehingga ada 80,4\% 
dipengaruhi variabel lain diluar model ini yang tidak diselidiki dalam penelitian ini misalnya motivasi belajar, kecemasan, perilaku, karakter dan lain-lain. Variabel-variabel tersebut yang kemungkinan mengakibatkan belum maksimalnya variabel kemandirian belajar matematika yang dicapai siswa. Berdasarkan perhitungan effect size dapat disimpulkan bahwa persamaan struktural 4.1 memiliki effect size dalam kategori sedang. Dengan kata lain aktivitas belajar matematika mempunyai kekuatan pengaruh yang sedang dalam mempengaruhi kemandirian belajar matematika siswa.

Persamaan struktural dan korelasi multipel kuadrat (4.2) mengandung arti bahwa sekitar $43,7 \%$ variabel hasil belajar matematika siswa dapat dijelaskan oleh aktivitas belajar dan kemandirian belajar secara bersama-sama. Sehingga masih ada 56,3\% dipengaruhi variabel lain diluar model ini yang tidak diselidiki dalam penelitian ini misalnya motivasi belajar, kecemasan, perilaku, karakter dan lain-lain. Variabel-variabel tersebut yang kemungkinan mengakibatkan belum maksimalnya hasil belajar matematika yang dicapai siswa. Berdasarkan perhitungan effect size dapat disimpulkan bahwa persamaan struktural 4.2 memiliki effect size dalam kategori besar. Dengan kata lain aktivitas belajar dan kemandirian belajar mempunyai kekuatan pengaruh yang besar dalam mempengaruhi hasil belajar matematika siswa.

Model struktural pengaruh faktor-faktor eksogen dan indogen terhadap hasil belajar matematika tersebut menyatakan bahwa makin baik faktor aktivitas belajar dan kemandirian belajar yang dimiliki siswa dan makin baik aktivitas belajar yang dilakukan siswa maka semakin baik kemandirian belajar matematika siswa SMP Negeri 21 Ambon, begitu pula sebaliknya.

Berdasarkan hasil pengujian terhadap hipotesis 1 dengan menggunakan software AMOS (Analysis of Moment Structure) untuk melihat pengaruh langsung aktivitas belajar (X) terhadap kemandirian belajar (Y1), besar pengaruh secara langsung variabel aktivitas belajar terhadap kemandirian belajar sebesar $19,6 \%$ dengan ukuran pengaruh pada kategori sedang. Hasil temuan tersebut menunjukkan bahwa aktivitas belajar berpengaruh positif dan signifikan terhadap kemandirian belajar matematika siswa SMP Negeri 21 Ambon. Hal ini menunjukkan bahwa siswa yang memiliki aktivitas belajar yang tinggi (membaca buku, menyalin/ mencatat/ membuat rangkuman, menggambar/membuat grafik/ diagram/ peta dan pola, berusaha memecahkan soal yang berhubungan dengan matematika, mengingat materi yang disampaikan dan membuat kesimpulan) akan mampu mengatur kegiatan belajarnya sendiri (kemandirian belajar). Sedangkan siswa yang memiliki aktivitas belajar yang buruk berdampak buruk terhadap kemandirian belajarnya.

Berdasarkan hasil pengujian terhadap hipotesis 2 dengan menggunakan software AMOS (Analysis of Moment Structure) untuk melihat pengaruh langsung aktivitas belajar (X) terhadap hasil belajar matematika (Y2), besar pengaruh secara langsung variabel aktivitas belajar terhadap hasil belajar matematika sebesar 18,66\% dengan ukuran pengaruh pada kategori sedang. Hasil temuan tersebut menunjukkan bahwa aktivitas belajar berpengaruh positif dan signifikan terhadap hasil belajar matematika siswa SMP Negeri 21 Ambon. Hal ini menunjukkan bahwa siswa yang memiliki aktivitas belajar yang baik cenderung semakin baik hasil belajar yang diperoleh. Sebaliknya, siswa yang memiliki aktivitas belajar yang buruk berdampak buruk terhadap hasil belajarnya.

Hasil temuan dari peneliti sejalan dengan hasil penelitian Ernawati (2013: 110) yang menunjukkan bahwa aktivitas belajar berpengaruh positif dan signifikan terhadap hasil belajar matematika secara langsung dengan besar koefisien jalur secara langsung sebesar 0,439.

Berdasarkan pengujian terhadap hipotesis 3 dengan menggunakan software AMOS (Analysis of Moment Structure) untuk melihat pengaruh langsung kemandirian belajar (Y1) terhadap hasil belajar matematika (Y2), besar pengaruh yang diperoleh sebesar 11,9\% dengan ukuran pengaruh pada kategori kecil. Hasil temuan tersebut menunjukkan bahwa kemandirian belajar berpengaruh positif dan signifikan terhadap hasil belajar matematika siswa SMP Negeri 21 Ambon. Artinya, semakin baik siswa mandiri dalam belajar (mengatasi masalah sendiri, berperilaku/mengambil keputusan berdasarkan inisiatif sendiri, memiliki kepercayaan diri terhadap keputusan yang diambil, merasa apa yang dilakukan benar dan memiliki keyakinan mantap/ teguh pendirian) maka akan cenderung semakin baik pula hasil belajar siswa.

Temuan ini sejalan dengan hasil penelitian Anwari (2011) yang menyatakan bahwa terdapat pengaruh yang signifikan antara kemandirian belajar terhadap prestasi belajar ekonomi siswa kelas XI SMA Negeri 3 Sukoharjo Tahun Ajaran 2010/2011. Sejalan dengan temuan Anwari, Agustina (2010) menyimpulkan bahwa ada pengaruh yang signifikan kemandirian belajar siswa terhadap prestasi belajar pada mata diklat KKPI siswa kelas XI jurusan Administrasi 
Perkantoran SMK Negeri I Karanganyar tahun pelajaran 2009/2010 yang ditunjukkan dengann harga r-hitung $>$ r-tabel atau 0,552 > 0,312 dengan taraf signifikansi $5 \%$.

Berdasarkan hasil pengujian hipotesis 4 dengan menggunakan software AMOS (Analysis of Moment Structure) untuk melihat pengaruh tidak langsung aktivitas belajar (X) terhadap hasil belajar (Y2) melalui kemandirian belajar (Y1) diperoleh koefisien regresi standardized indirect effect sebesar sebesar 0,153 atau sebesar 2,34\% dengan ukuran pengaruh pada kategori kecil. Hal ini menunjukkan bahwa aktivitas belajar berpengaruh positif dan signifikan terhadap hasil belajar matematika melalui kemandirian belajar matematika siswa SMP Negeri 21 Ambon. Hasil penelitian ini mengindikasikan bahwa kemandirian belajar matematika merupakan variabel intervening antara pengaruh positif aktivitas belajar terhadap hasil belajar matematika. Kemandirian belajar matematika memperkuat pengaruh aktivitas belajar terhadap hasil belajar matematika. Artinya, pengaruh aktivitas belajar terhadap hasil belajar matematika siswa SMP Negeri 21 Ambon akan semakin tinggi jika disertai dengan kemandirian belajar matematika siswa yang tinggi.

Hasil temuan dari peneliti sejalan dengan hasil penelitian Ernawati (2013: 110) yang menunjukkan bahwa aktivitas belajar berpengaruh positif dan signifikan terhadap hasil belajar matematika secara tidak langsung melalui kemandirian. Hal tersebut dapat dilihat dari besar koefisien jalur yang tidak langsung (melalui kemandirian belajar $\left(\mathrm{X}_{4}\right)$ sebesar 0,608.

Berdasarkan hasil pengujian hipotesis 5 dengan menggunakan software AMOS (Analysis of Moment Structure) untuk melihat total pengaruh aktivitas belajar (X) terhadap hasil belajar matematika (Y2) baik secara langsung maupun tidak langsung melalui kemandirian belajar diperoleh koefisien regresi standardized total effects sebesar 0,584 atau sebesar 34,1\% dengan ukuran pengaruh berada pada kategori besar. Hasil temuan tersebut menunjukkan bahwa total pengaruh aktivitas belajar terhadap hasil belajar matematika siswa SMP Negeri 21 Ambon baik secara langsung maupun secara tidak langsung adalah positif dan signifikan.

Hasil temuan dari peneliti sejalan dengan hasil penelitian Ernawati (2013: 110) yang menunjukkan bahwa aktivitas belajar berpengaruh positif dan signifikan terhadap hasil belajar matematika baik secara langsung maupun tidak langsung (melalui kemandirian belajar).

\section{Kesimpulan}

Berdasarkan hasil analisis data penelitian pada bab sebelumnya, beberapa kesimpulan dari hasil penelitian ini adalah:

a. Besar pengaruh aktivitas belajar terhadap kemandirian belajar siswa SMP Negeri 21 Ambon secara langsung adalah 19,6\% dengan ukuran pengaruh pada kategori sedang.

b. Besar pengaruh aktivitas belajar terhadap hasil belajar matematika siswa SMP Negeri 21 Ambon secara langsung adalah 18,66\% dengan ukuran pengaruh pada kategori sedang.

c. Besar pengaruh kemandirian belajar terhadap hasil belajar matematika siswa SMP Negeri 21 Ambon secara langsung adalah 11,9\% dengan ukuran pengaruh pada kategori kecil.

d. Besar pengaruh aktivitas belajar terhadap hasil belajar matematika siswa SMP Negeri 21 Ambon secara tidak langsung melalui kemandirian belajar adalah $2,34 \%$ dengan ukuran pengaruh pada kategori kecil.

e. Besar total pengaruh aktivitas belajar terhadap hasil belajar matematika siswa SMP Negeri 21 Ambon baik secara langsung maupun tidak langsung (melalui kemandirian belajar) adalah $34,1 \%$ dengan ukuran pengaruh berada pada kategori besar.

Bertitik tolak dari kesimpulan penelitian, dapat diajukan beberapa saran yang diharapkan dapat memberi kontribusi dalam meningkatkan hasil belajar siswa dalam kaitannya dengan faktor-faktor internal khususya aktivitas belajar dan kemandirian belajar. Adapun saran yang dapat disampaikan adalah sebagai berikut:

a. Guru perlu merancang dan mengembangkan pembelajaran yang melibatkan aktivas belajar siswa secara optimal.

b. Guru perlu memfasilitasi tumbuh kembangnya kemandirian belajar pada siswa, misalnya dengan memotivasi siswa, merancang tugas-tugas yang lebih menarik untuk dikerjakan di luar tatap muka, mendampingi kegiatan belajar siswa, dsb.

\section{Daftar Pustaka}

Agustina, S. 2010. Pengaruh Kemandirian Belajar Siswa dan Fasilitas Belajar Di Sekolah terhadap Prestasi Belajar Keterampilan Komputer Dan Pengelolaan Informasi (Kkpi) Siswa Kelas XI Jurusan Administrasi Perkantoran SMK Negeri I Karanganyar Tahun Pelajaran 2009/2010. Skripsi. (online), Tersedia http://digilib. fkip. uns.ac.id/ contents/ skripsi. php?id_skr=554 (diakses 27 April 2014). 
Anwari, T. 2011. Pengaruh Kemandirian Belajar Siswa dan Intensitas Pemanfaatan Perpustakaan Sekolah terhadap Prestasi Belajar Mata Pelajaran Ekonomi Siswa Kelas XI SMA N 3 Sukoharjo Tahun Ajaran 2010/2011. Skripsi. (online), Tersedia http://library.uns.ac.id/digilib/dokumen/detail/2 4541 (diakses 27 April 2014).

Assagaf, G. 2014. Pengaruh Kemandirian Belajar dan Regulasi Diri terhadap Hasil Belajar Matematika melalui Motivasi Berprestasi pada Siswa Kelas X SMA Negeri di Kota Ambon. Tesis. Tidak diterbitkan. Makassar: UNM

Ernawati. 2013. Pengaruh Efikasi Diri, Konsep Diri, Aktivitas Belajar dan Kemandirian Belajar terhadap Hasil Belajar Matematika pada Siswa Kelas VII SMP Negeri Se-Kecematan Somba Oри. Tesis. Tidak diterbitkan. Makassar: UNM.

Kasliyanto. 2014. Pengaruh Kecerdasan Emosional dan Iklim Sekolah terhadap Hasil Belajar Matematika Siswa melalui Perilaku Belajar, Regulasi Diri dan Kecerdasan Belajar Siswa Kelas X SMA Negeri Di Kota Ambon. Tesis. Tidak diterbitkan. Makassar: UNM.

Nurhayati, E. 2011. Psikologi Pendidikan inovatif. Yogyakarta: Pustaka Pelajar.

Ratumanan, 2015. Analisis Penguasaan Objek Matematika pada Lulusan SMA di Provinsi Maluku Tahun 2015. Ambon: FKIP Unpatti.

Yamin, M. 2013. Kiat Membelajarkan Siswa. Ciputat: Referensi (GP Press Group). 